\title{
POLA DAKWAH NAHDLATUL ULAMA DI KOTA BANJARMASIN
}

\section{Fahmi Riady}

email: fahmiriady@gmail.com

Dosen Tetap Pada Jurusan Komunikasi dan Penyiaran Islam

IAIN Banjarmasin

\section{Abstract:}

Nahdlatul Ulama (NU) is a big organization in Indonesia and it spreads to the entire areas in Indonesia from Aceh to Papua. In central area of Indonesia, precisely in Banjarmasin, NU can exists and recruits a lot of followers who are generally Pesantren-graduates, which are called "Nahdliyyin". This paper employed a science of da'wah approach with a focus on "NU's pattern of da'wah in Banjarmasin", which includes verbal, action, and written models of preaching (da'wah bil lisan, bil hal wa bil kitab). This showed that NU tends to use verbal and action model of da'wah rather than the written one, such as magazine, newspaper, and so on. This differs from other Islamic organizations such as Muhammadiyah and Al-Irsyad in Banjarmasin. However, the contribution of NU in developing and spreading da'wah and NU's mission is significant despite the fact that it is carried out personally and not on behalf of the organization to which the community can look and recognize it as NU's Islamic preaching.

$$
\begin{aligned}
& \text { نهضة العلماء هي من أكبر المنظمات الإسلامية فى إندونيسيا و كانت تنتشر إلى جميع أنحاء المناطق }
\end{aligned}
$$

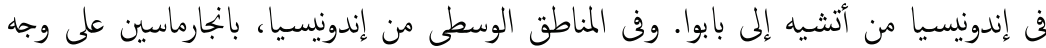

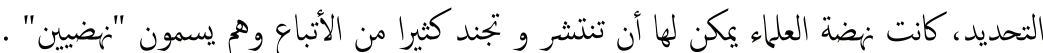

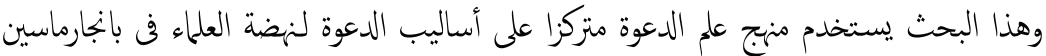

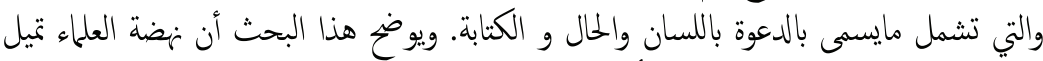

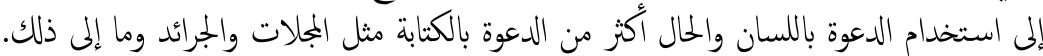

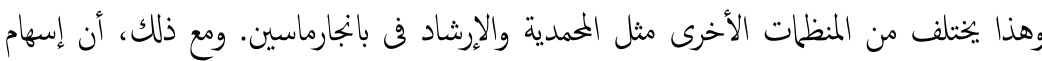

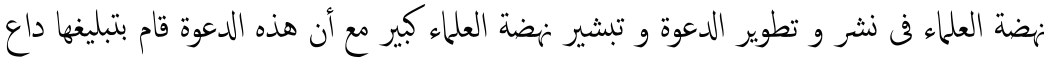

$$
\begin{aligned}
& \text { نفسه ليس نيابة عن منظمة نهضة العلماء. }
\end{aligned}
$$

Kata Kunci: pola, dakwah, nahdlatul ulama 
Fahmi Riady, Pola Dakwah Nahdlatul Ulama di Kota Banjarmasin

\section{A. Pendahuluan}

Kehadiran agama di dunia adalah sebagai penghubung antara manusia dan Tuhan. Dengan agama, manusia berjalan menuju Tuhan, mencari ridha-Nya melalui peribadatan dan amal saleh berdimensi kemanusiaan. Keyakinan manusia pada agama sebagai jalan tidak lepas dari utusan-utusan yang mewakili kehendak Tuhan. Maka menjadi amat penting sosok seorang juru bicara dalam konstelasi keberagamaan.

Dalam Islam, tokoh sentral yang keberadaannya tidak bisa dinafikan adalah nabi Muhammad. Beliau dengan ide-ide besar yang dititipkan Tuhan melalui Alqurān mampu melakukan perubahan besarbesaran di bumi Arab. ${ }^{1}$ Dari masyarakat liar yang tidak beradab, menjadi masyarakat yang taat aturan. Dari masyarakat pagan, menjadi masyarakat monoteisme. Dari kejahiliyahan sikap, menjadi masyarakat cerdas, peka, dan melek kemanusiaan.

Dengan adanya ide dan tokoh sentral inilah Islam mulai dikenal luas. Di tambah lagi dengan gerakan masyarakat tauhid yang dikenal dengan sebutan ummah, semakin kuatlah bangunan Islam sebagai agama kemanusiaan yang membebaskan. Dapat dikatakan, Islam masa nabi dan sahabat adalah Islam ideal, sempurna dan seharusnya mendapat perhatian untuk diteladani.

Pasca nabi Muhammad, Islam yang diyakini sebagai jalan keselamatan terus diperjuangkan. Ide-ide besarnya masih tetap sama, yaitu sebagaimana yang terdapat di dalam Alqurān, berikut tambahan dari warisan praktik keberislaman nabi Muhammad yang dikenal dengan istilah hadits. Dua pokok doktrin ini dikenal juga sebagai pedoman keselamatan, karena itu harus terus disebarluaskan.

\footnotetext{
${ }^{1}$ Sebagaimana yang dikutip oleh Jalaluddin Rakhmat, bahwa perubahan sosial disebabkan oleh ideas, pandangan hidup, pandangan dunia, dan nilai-nilai, lihat Jalaluddin Rakhmat, Rekayasa Sosial: Reformasi, Ravolusi, atau Manusia Besar? (Bandung: Remaja Rosda Karya, 2000), h. 47.
} 


\section{$\Delta L-n i s h \exists \bar{\Delta} h$,Vol. 11 No. 1, Januari-Juni 2015: 67-104}

Ummah sebagai gerakan sosial keagamaan menjelma dalam ragam yang banyak. Dari masa klasik hingga modern bentuknya berbedabeda. Namun tetap memiliki misi yang sama, yaitu berdakwah, mengajak orang untuk masuk pada jalan keselamatan agar sampai dengan afiat ke hadirat Tuhan.

Sosok nabi Muhammad sebagai seorang manusia pemanggul wahyu memang tidak bisa digantikan. Akan tetapi misi beliau mengajak manusia pada keselamatan dapat diisi oleh manusia Islam dari belahan bumi manapun. Karena itu, dari masa ke masa terus bermunculan orang yang mengemban misi tersebut. Caranya macam-macam. Ada yang bersifat perorangan, dan ada juga yang berkelompok.

Di Indonesia, banyak orang yang melanjutkan misi kenabian ini. Di antaranya ada yang bergabung dengan organisasi-organisasi besar seperti Muhammadiyah (1912), al-Irsyad (1914), Persis (1923), dan Nahdhatul Ulama (1926). Dengan nama berbeda berikut latar belakang yang berbeda pula. Organisasi-organisasi ini hampir memiliki misi yang sama, sebagaimana yang ditilaskan oleh Nabi Muhammad, yaitu menyelamatkan manusia.

Pengelompokan Islam dalam berbagai organisasi seperti tersebut di atas, memberikan gambaran bahwa misi besar Islam pada aspek tertentu harus mendapat penekanan. Umpamanya, Nahdhatul Ulama yang pada awalnya didirikan untuk menampung para ulama pesantren dalam suatu organisasi agar lebih menyatu dan memiliki irama yang sama dalam berdakwah, melebarkan misinya dalam wilayah sosial, ekonomi, dan politik. ${ }^{2}$

Ada banyak lagi kiranya sebaran pola dakwah yang Nahdlatul Ulama lakukan baik secara massif maupun parsial. Menarik untuk diteliti, bahwa pertama, Nahdlatul Ulama adalah organisasi terbesar yang ada di

${ }^{2}$ Lihat Muhamad Mukhsin Jamil, dkk., Nalar Islam Nusantara (Jakarta: DPTI, 2007), h. 17-277. 
Fahmi Riady, Pola Dakwah Nahdlatul Ulama di Kota Banjarmasin

Kota Banjarmasin. Kedua, organisasi ini dalam praktik keberagamaannya mudah dikenali. Ketiga, memiliki banyak amal usaha. Keempat, tokohtokohnya banyak dan mudah untuk didekati. Kelima, pola dakwahnya beragam dan menarik.

Maka berdasarkan alasan-alasan tersebut di atas, penulis menfokuskan bahasan pada dua hal, "bagaimana sejarah Nahdlatul Ulama di Kota Banjarmasin dan bagaimana pola dakwah Nahdlatul Ulama di Kota Banjarmasin ?" Inilah yang menjadi kajian utama dalam tulisan ini.

\section{B. Kajian Pustaka}

\section{Pengertian Dakwah Islam}

Dakwah berasal dari kata kerja da'ā-yad'ū yang berarti menyeru, memanggil, atau mengajak. Dalam Ilmu Tata Bahasa Arab, kata dakwah berbentuk ism masdar ${ }^{3}$ yang berarti mengajak umat manusia dengan hikmah kebijaksanaan untuk mengikuti petunjuk Allah dan rasul-Nya. ${ }^{4}$ Definisi lain, sebagaimana yang dikutip oleh Asmuni Syukir dalam buku "Metodologi Dakwah Kepada Suku Terasing", dakwah adalah setiap usaha yang mengarah untuk memperbaiki suasana kehidupan yang lebih baik dan layak, sesuai dengan kehendak dan tuntunan kebenaran. ${ }^{5}$

Dalam Wikipedia disebutkan, dakwah adalah kegiatan yang bersifat menyeru, mengajak, dan memanggil orang untuk beriman dan taat kepada Allah sesuai dengan garis aqidah, syari'ah, dan akhlak Islam. ${ }^{6}$ Dan menurut Abu Bakar Zakaria, dakwah adalah usaha para ulama dan

h. 17 .

${ }^{3}$ Asmuni Syukir, Dasar-Dasar Strategi Dakwah Islam, (Surabaya: al-Ikhlas, 1983),

${ }^{4}$ Hamzah Ya'qub, Publisistik Islam: Teknik dakwah dan Leadership (Bandung: Diponegoro, 1981), h. 13.

${ }^{5}$ Asmuni Syukir, Dasar-Dasar..., h. 20.

${ }^{6}$ http://id.wikipedia.org, Dakwah (15 November 2010). 
orang-orang yang memiliki pengertian tentang agama Islam untuk memberikan pengajaran kepada khalayak umum akan hal-hal yang menimbulkan pengertian mereka berkenaan dengan urusan agama dan keduniaannya menurut kemampuan. ${ }^{7}$

Dari berbagai definisi di atas, meski terdapat kesamaan dan perbedaan, namun juga terdapat hal-hal sebagai berikut: Pertama, bahwa dakwah adalah suatu usaha atau proses yang diselenggarakan dengan sadar dan terencana. Kedua, usaha yang dilakukan adalah mengajak umat manusia ke jalan Allah, memperbaiki situasi yang lebih baik (dakwah bersifat pembinaan dan pengembangan). Ketiga, usaha tersebut dilakukan dalam rangka mencapai tujuan tertentu, yakni agar hidup bahagia sejahtera di dunia atau di akhirat. ${ }^{8}$

Kata dakwah sering juga disamakan dengan istilah-istilah seperti tabligh, amar ma'ruf nahi munkar, washiyah (memberi wasiat), nashihah (memberi nasehat), khotbah, jihadah (berjuang), mauizhah (nasehat atau memberi pelajaran), mujadalah (berdebat atau berdiskusi), tadzkirah (peringatan), dan indzar (memberi peringatan).

Dari beberapa istilah ini tampak bahwa usaha dakwah ini terjadi dalam komunikasi antara sesama manusia, baik secara langsung maupun tidak langsung, secara orang seorang atau kelompok. Jelas bahwa dakwah termasuk salah satu macam komunikasi, sebab unsur-unsur yang ada dalam kegiatan dakwah telah memenuhi syarat untuk dikatakan sebagai komunikasi. Dan dalam kajian teori ini, terlebih dahulu akan dibicarakan hal-hal yang berkenaan dengan unsur-unsur dakwah.

\section{Unsur-Unsur dalam Dakwah}

Unsur-unsur dakwah adalah segala aspek yang ada sangkut pautnya dengan proses pelaksanaan dakwah, dan sekaligus menyangkut 1993), h. 10 .

${ }^{7}$ M. Hafi Anshari, Pemahaman dan Pengalaman Dakwah (Surabaya: al-Ikhlas,

${ }^{8}$ Asmuni Syukir, Dasar-Dasar..., h. 21. 
Fahmi Riady, Pola Dakwah Nahdlatul Ulama di Kota Banjarmasin

keberlangsungannya. Banyak unsur yang harus diperhatikan bagi pelaksana dakwah agar dakwah itu dapat dilaksanakan dengan baik, intensif, dan efesien. Unsur-unsur dakwah itu meliputi:

a. Subjek Dakwah

Subjek dakwah ialah orang yang melakukan dakwah, yaitu orang yang berusaha merubah situasi kepada situasi yang sesuai dengan ketentuan-ketentuan Allah, baik secara individu maupun berbentuk kelompok (organisasi), sekaligus sebagai pemberi informasi dan pembawa misi. ${ }^{9}$ Seperti tersebut di dalam surah Ali Imrān/3:104:

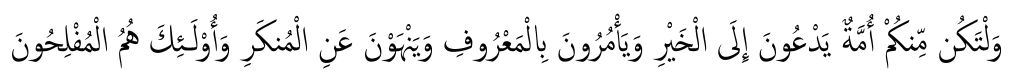

Terjemahnya:

"Dan hendaklah di antara kamu ada segolongan orang yang menyeru kepada kebajikan, menyuruh (berbuat) yang ma'ruf, dan mencegah dari yang munkar dan mereka itulah orang-orang yang beruntung." 10

Sebenarnya jika diperhatikan secara seksama, cakupan ayat Alqurān surah Ali Imrān (3): 104 ini cukup luas, di antaranya adalah kewajiban dakwah dalam arti pelaku dakwah, obyek dakwah, materi dakwah, langkah-langkah dakwah (berkaitan metode dan sarana), dan tujuan akhir dakwah. Ayat ini secara tegas menjelaskan bagaimana menegakkan dan memelihara masyarakat yang beriman dan bertakwa kepada Allah dengan jalan dakwah dengan anjuran amar ma'ruf dan nahī munkar.

Terkait dengan pembahasan yang pertama, yaitu subjek dakwah, dalam beberapa tafsir disebutkan tentang apakah kewajiban dakwah tertuju kepada setiap individu atau sebagian individu saja yang memiliki

\footnotetext{
${ }^{9}$ M. Hafi Anshari, Pemahaman..., h. 105.

${ }^{10}$ Departemen Agama RI, Alqur'an dan Terjemahnya, (Bandung: Fokus Media,
} 2010), h. 63. 


\section{$\Delta L-\cap i s h \exists \bar{\Delta} h$,Vol. 11 No. 1, Januari-Juni 2015: 67-104}

kompetensi. Ini dapat dilihat pada pembahasan kata minkum (منكم). Apakah kata min di sana bermakna tab'id (ba'diyyah) ataukah tabyin (bayaniyyah). Pendapat pertama yang melihat min sebagai ba'diyyah, maka kewajiban dakwah itu tidak tertuju kepada setiap individu, tetapi kepada sebahagian yang memiliki kompetensi, baik kompetensi ilmu, visi dan ketrampilan menjalankan kegiatan dakwah dan amar ma'ruf dan nahī munkar.

Pendapat yang kedua yang memandang min sebagai bayaniyyah, berimplikasi pada pemahaman bahwa kewajiban dakwah jatuh kepada setiap individu, tanpa kecuali. Pemahaman ini diperkuat dengan isyarat dalam surah al-'Aṣr (103): 1-3, ${ }^{11}$ yang menyatakan bahwa orang yang tidak ingin jatuh kepada kehancuran, kerugian, tidak ada jalan lain kecuali dengan beriman, beramal dan saling berpesan dalam kebenaran dan berpesan untuk tetap bersabar.

Beberapa ulama mengkompromikan dua pendapat tersebut. Quraish Shihab dalam tafsir al-Mishbah menjelaskan bahwa jika dakwah yang dimaksud adalah dakwah yang sempurna, yakni dakwah yang sistematis, terencana program dan langkah-langkahnya, maka hal itu menjadi kewajiban bagi mereka yang memiliki kompetensi. Untuk itu ia menjadi wajib kifāyah. Sedangkan jika dakwah dimaknai sebagai ajakan atau tausiyah tentang kebenaran (al-haq) sesuai dengan kemampuan masing-masing, maka dakwah adalah kewajiban individual (wajib ain). ${ }^{12}$

Kemudian, terkait dengan terminologi al-ummah al-da'iyyah, alRaghib al-Asfahani menyebutkan, bahwa kata al-ummah berakar pada kata al-umm yang berarti induk (asl al-mas'alah), ibu (orang tua serempuan, al-walidah). la mendefinisikan al-umm sebagai كل شيئ ضم اليه

${ }^{11}$ Departemen Agama RI, Alqurān dan...., h. 601.

${ }^{12}$ Quraish Shihab, Tafsir al-Miṣbah Pesan, Kesan, dan Keserasian Alqurān, volume 2 (Jakarta:Lentera Hati), h. 162. 
Fahmi Riady, Pola Dakwah Nahdlatul Ulama di Kota Banjarmasin

سائر ما يليه يسمى أما yaitu segala sesuatu yang pantas disebut ibu. ${ }^{13}$ Sementara untuk kata al-ummah didefinisikannya sebagai:

$$
\text { أوامة : كل جاعة يجمعهم أمر واحد إما دين واحد أو زمان واحد أو مكان واحد سواءكان ذلك الامر الجامع تسخيرا }
$$

Secara sederhana, kata ummah di atas dapat diartikan sebagai setiap kelompok yang diorganisir oleh suatu hal yang sama, apakah itu agama, waktu, atau tempat, baik hal itu bersifat kepatuhan atau pilihan. ${ }^{14}$ Karena itu dapat disimpulkan, bahwa yang dimaksud ummah dalam surah Ali Imrān (3) : 104 adalah suatu kelompok yang terorganisir, baik itu dalam konteks kepemimpinan, keanggotaan, atau hubungan antar keduanya. Organisasi dakwah mempunyai kegiatan yang lebih konsepsional di dalam program kerja, lebih bersifat formal karena mempunyai landasan dan Anggaran Rumah Tangga, dan bersifat lebih umum dan luas, sebab didukung oleh semua bagian organisasi atau anak organisasinya dan seluruh anggota yang mendukungnya.

Menurut Anshari, dalam organisasi perlu diadakan hubungan antara subjek dan subjek. Yang dimaksud hubungan antara subjek dan subjek adalah hubungan antara da'i yang satu dengan da'i yang lainnya, atau hubungan antara organisasi dakwah yang satu dengan organisasi dakwah yang lain, yang di antaranya seperti: perlu adanya shilaturrahmi, perlu adanya pembicaraan-pembicaraan seperti musyawarah atau diskusi, seminar dan bentuk-bentuk lain yang sekiranya saling menguntungkan dan menunjang. Sementara bagi da'i yang merupakan salah satu anggota organisasi, perlu mentaati ketentuan-ketentuan organisasi. ${ }^{15}$

\footnotetext{
${ }^{13}$ Al-Raghib al-Asfihani, Mu'jām Mufradāt al-Fazhil Qurān (Beirut: Darul Fikri, tth), h. 18.

${ }^{14}$ Al-Raghib al-Asfihani, Mu'jām Mufradāt...h. 19.

${ }^{15}$ M. Hafi Anshari, Pemahaman..., h. 117.
} 


\section{$\Delta L-\cap i s h \exists \bar{\Delta} h$,Vol. 11 No. 1, Januari-Juni 2015: 67-104}

Adapun untuk subjek dalam arti individu, Anshari menyebutkan bahwa setidaknya seorang da'i itu memenuhi persyaratan seperti: Jasmani/atau fisik yang sehat, memiliki pemahaman yang baik akan keseluruhan unsur-unsur dakwah, dan memiliki kepribadian, atau kualitas pribadi yang bagus. ${ }^{16}$

Al-Maraghi menjelaskan tentang syarat-syarat da'i yang akan menegakkan amar ma'ruf nahi munkar, yaitu: Pertama, hendaknya memahami Alqurān, al-Sunnah, Sirah Nabawiyah dan Sahabat. Kedua, hendaknya pandai membaca situasi orang-orang yang akan dan sedang menerima dakwahnya, meliputi minat, kemampuan, sosio-kultural, tabi'at dan akhlaknya. Ketiga, memahami bahasa umat yang dituju oleh dakwahnya, termasuk kebudayaannya. Keempat, mengetahui agamaagama, aliran-aliran yang ada di masyarakat, agar juru dakwah dapat mengetahui dan menjelaskan kelemahan dan kekeliruan agama-agama dan aliran-aliran yang ada, dan menunjukkan keunggulan agama Islam. ${ }^{17}$

Sejalan dengan Al-Maraghi, Hamka menyebutkan ada sebelas perkara yang perlu diperhatikan subjek dakwah: Pertama, hendaknya seorang da'i mempunyai pengetahuan yang sempurna. Kedua, berpengetahuan tentang keadaan umat. Ketiga, wajib berpengetahuan tentang pokok dan sumber sejarah yang umum, supaya dapat mengetahui dari mana sumber kerusakan akhlak dan timbulnya adat istiadat yang menggangu kecerdasan berpikir. Keempat, hendaknya da'i berpengetahuan ilmu bumi. Kelima, mengetahui ilmu jiwa. Keenam, mengetahui ilmu akhlak. Ketujuh, mengetahui ilmu masyarakat (sosiologi). Kedelapan, mengetahui ilmu politik. Kesembilan, mengetahui bahasa negeri tempat melakukan dakwah supaya dapat menyelami jiwa yang empunya bahasa. Kesepuluh, megetahui kebudayaan dan kesenian.

\footnotetext{
${ }^{16}$ M. Hafi Anshari, Pemahaman..., h. 107.

${ }^{17}$ Ahmad Musthafa al-Maraghi, Tafsir al-Maraghi, juz IV (Beirut: Darul Fikri, th), h. 23 .
} 
Fahmi Riady, Pola Dakwah Nahdlatul Ulama di Kota Banjarmasin

Kesebelas, mengetahui pokok-pokok perbedaan agama-agama yang ada. $^{18}$

Demikianlah, suksesnya kegiatan dakwah tergantung bagaimana da'inya, baik dalam arti individu atau dalam bentuk organisasi. Semua akan berjalan dengan baik kalau syarat-syarat yang tersebut di atas terpenuhi. Dan dakwah secara terorganisir adalah ciri dakwah modern.

b. Objek Dakwah

Objek dakwah atau penerima dakwah tidak lain adalah manusia, baik seorang atau lebih, yaitu masyarakat. Pemahaman mengenai masyarakat itu bisa beragam, tergantung dari cara memandangnya. Dipandang dari bidang sosiologi, masyarakat itu memiliki struktur dan mengalami perubahan-perubahan. Di dalam Masyarakat terjadi interaksi antara satu orang dengan orang lain, antara satu kelompok dengan kelompok lain, individu dengan kelompok.

Di dalam masyarakat terdapat kelompok-kelompok, lapisanlapisan, lembaga-lembaga, nilai-nilai, norma-norma, kekuasaan, proses perubahan. Itulah pandangan sosiologis terhadap masyarakat. Pandangan psikologis lain lagi, demikian pula pandangan dari bidang antropologi, sejarah, ekonomi, agama, dan sebagainya. ${ }^{19}$ Karena itu menurut Hamzah Ya'qub, sebelum mempengaruhi masyarakat atau seseorang yang menjadi sasaran dakwah, maka masyarakat itu perlu dipelajari terlebih dahulu. ${ }^{20}$ Dari itu seorang da'i perlu memperhatikan apa yang telah disebutkan oleh Hamka di atas.

Untuk mengetahui keadaan masyarakat, perlu diadakan klasifikasi (pembagian) masyarakat menurut derajat pikirannya: Pertama, masyarakat yang berpikir kritis. Kelompok ini adalah tergolong masyarakat yang berpendidikan dan orang-orang yang berpengalaman.

\footnotetext{
${ }^{18}$ Hamka, Tafsir al-Azhar, juz IV (Jakarta: Pustaka Panjimas, 1987), h. 40.

${ }^{19}$ Wardi Bachtiar, Metodologi Penelitian..., h. 36.

${ }^{20}$ Hamzah Ya'qub, Publisistik Islam..., h. 32.
} 
Orang-orang ini hanya dapat dipengaruhi hanya kalau pikirannya menerima dengan baik. Golongan ini disebut masyarakat rasional. Kedua, masyarakat yang mudah dipengaruhi. Biasanya masyarakat seperti ini suka mengikuti apa yang banyak dilakukan orang. Mereka ini sering disebut dengan masyarakat irrasional. Ketiga, masyarakat yang bertaklid. Mereka ini adalah kelompok fanatik buta, mengikuti tradisi nenek moyang mereka, sebaliknya, apa yang bertentangan dengan tradisi, mereka anggap salah. Atau ada juga jenis taklid yang mengikuti suatu paham, pendirian, aliran, atau agama. ${ }^{21}$

Kemudian menurut Hamzah Ya'qub, selain pembagian menurut derajat pikir tersebut di atas, masyarakat dapat pula dibagi menurut bidang pekerjaan mereka, antara lain seperti: buruh, petani, nelayan, pegawai, militer, seniman, dan lain-lain. Atau juga dibagi menurut biologisnya, laki-laki dan perempuan. Juga berdasarkan struktur menurut usia: anak-anak, remaja, pemuda, tua, dan seterusnya. Juga berdasarkan ekonominya, dan terakhir berdasarkan geografisnya. ${ }^{22}$

\section{c. Materi Dakwah}

Materi dakwah adalah pesan-pesan yang disampaikan oleh subjek dakwah kepada objek dakwah, yaitu keseluruhan ajaran Islam yang ada dalam Kitabullah maupun Sunnah Rasulullah yang pada pokoknya mengandung tiga prinsip, yaitu: 1). Aqidah, 2). Syariat, dan 3). Akhlak. ${ }^{23}$

Terkait dengan materi dakwah ini, Quraish Shihab menjelaskan, bahwa seorang da'i harus memperhatikan: Pertama, apakah materi yang disampaikan sesuai dengan harapan pendengar atau tidak. Kedua, apakah materi yang disampaikan kepada objek dakwah itu sudah saatnya atau belum. Ketiga, apakah materi yang disampaikan sangat teoritis, atau berhubungan langsung dengan pengalaman objek dakwah. Jika hal ini

\footnotetext{
${ }^{21}$ Ibid., h. 33.

${ }^{22}$ Ibid., h. 35.

${ }^{23}$ M. Hafi Anshari, Pemahaman..., h. 146.
} 
Fahmi Riady, Pola Dakwah Nahdlatul Ulama di Kota Banjarmasin

tidak diperhatikan menurut Shihab, boleh jadi seorang da'i akan mengalami kekeliruan dan kegagalan dalam pelaksanaan dakwahnya. ${ }^{24}$

c. Metode Dakwah

Metode dakwah adalah cara yang ditempuh oleh da'i dalam melaksanakan dakwahnya untuk mencapai tujuan dengan baik. Untuk itu bagi seorang da'i perlu melihat kemampuan yang ada pada dirinya dan juga melihat secara benar terhadap objek dalam segala seginya. ${ }^{25}$ Toto Tasmara menyimpulkan beberapa prinsip dan approach dan metode dakwah sebagai berikut: Pertama, approach dakwah senantiasa memperhatikan dan menempatkan penghargaan yang tinggi atas manusia dengan menghindari prinsip-prinsip yang akan membawa kepada sikap pemaksaan kehendak. Kedua, peranan hikmah dan kasih sayang adalah merupakan yang paling dominan dalam proses penyampaian idea-idea dalam komunikasi dakwah tersebut. Ketiga, approach dakwah yang bertumpu pada human oriented menghargai keputusan final yang diambil oleh pihak komunikan, dan karenanya dakwah merupakan penyampaian/penerimaan idea-idea secara demokratis. Keempat, approach dakwah yang didasarkan atas hikmah dan kasih sayang itu, dapat memakai segala alat yang dibenarkan menurut hukum sepanjang hal tersebut tetap menghargai hak-hak menusia itu sendiri. ${ }^{26}$

Berkenaan dengan dakwah bil-ḥikmah, dalam Alqurān surah alNahl (16): 125 disebutkan:

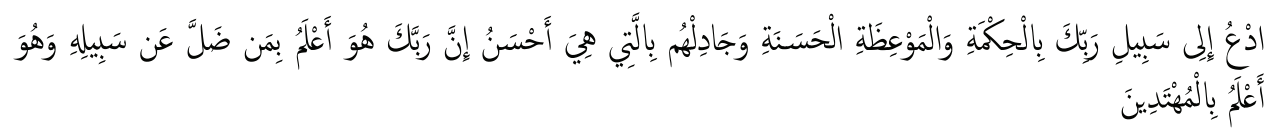

${ }^{24}$ Quraish Shihab, Membumikan Alqurān: Fungsi dan Peran Wahyu dalam Kehidupan Masyarakat (Bandung: Mizan,1999), h.200.

${ }^{25}$ M. Hafi Anshari, Pemahaman..., h. 158.

${ }^{26}$ Toto Tasmara, Komunikasi Dakwah (Jakarta: Gaya Media Pratama, 1997), h. 46. 


\section{$\Delta L-n i s h \exists \bar{\Delta} h$,Vol. 11 No. 1, Januari-Juni 2015: 67-104}

Terjemahnya:

"Serulah (manusia) kepada jalan Tuhanmu dengan hikmah dan pelajaran yang baik dan bantahlah mereka dengan cara yang baik. Sesungguhnya Tuhanmu Dialah yang lebih mengetahui tentang siapa yang tersesat dari jalan-Nya dan Dialah yang lebih mengetahui orang-orang yang mendapat petunjuk."27

Dalam ayat-ayat ini terdapat konsep-konsep yang berkaitan dengan metode dan strategi dakwah Islam, yaitu konsep al-hikmah, almaw'izah al-hasanah dan al-jidāl. Menurut Hamka, dengan al-hikmah maksudnya adalah suatu cara yang dapat menarik orang yang belum maju kecerdasannya dan tidak dapat dibantah oleh orang yang lebih pintar. Hikmah atau kebijaksanaan bukan saja dengan ucapan mulut, melainkan termasuk juga dengan tindakan dan sikap hidup. Adapun dengan al-maw'izah al-hasanah yaitu dengan pengajaran yang baik, atau pesan-pesan yang baik yang disampaikan sebagai nasehat, yang termasuk juga pendidikan ayah bunda dalam rumah tangga kepada anak-anaknya, dengan menunjukkan contoh beragama yang baik, dan pendidikan pengajaran di perguruan-perguruan. Sedangkan al-jidal billati hiya ahsan adalah bantahan dengan cara yang baik. Salah satunya adalah dengan cara membedakan pokok soal yang dibicarakan dengan perasaan benci atau sayang kepada pribadi orang yang tengah diajak berbantah. ${ }^{28}$

Asmuni Syukir menambahkan, bahwa dalam berdakwah, seorang da'i seyogiyanya memperhatikan faktor-faktor yang mempengaruhi pemilihan dan penggunaan suatu metode, agar metode yang dipilih dan digunakan benar-benar fungsional. Faktor-faktor yang dimaksudkan adalah: Pertama, tujuan, dengan berbagai jenis dan fungsinya. Kedua, sasaran dakwah (masyarakat/individual), dengan segala kebijakan/politik pemerintah, tingkat usia, pendidikan, peradaban (kebudayaan) dan lain

\footnotetext{
${ }^{27}$ Departemen Agama RI, Alqurān dan..., h. 281

${ }^{28}$ Hamka, Tafsir al-Azhar, juz XIII-XIV..., h. 321.
} 
sebagainya. Ketiga, situasi dan kondisi yang beraneka ragam keadaannya. Keempat, media dan fasilitas (logistik) yang tersedia, dengan berbagai macam kuantitas dan kualitasnnya. Kelima, kepribadian dan kemampuan seorang da'i/mubalighh. ${ }^{29}$

Dengan memperhatikan faktor-faktor tersebut di atas, seorang da'i dapat memilih metode-metode dakwah sebagai berikut: 1). Metode Ceramah. Ceramah adalah suatu teknik atau metode dakwah yang banyak diwarnai oleh karakteristik bicara oleh seorang da'i/mubalighh pada suatu aktivitas dakwah. Ceramah dapat pula bersifat propaganda, kampanye, berpidato, khutbah, sambutan, mengajar, dan sebagainya. ${ }^{30}$ 2). Metode Tanya Jawab. Metode tanya jawab adalah penyampaian materi dakwah dengan cara mendorong sasarannya (objek dakwah) untuk menyatakan suatu masalah yang dirasa belum dimengerti dan mubalighh/da'i sebagai penjawabnya. ${ }^{31} 3$ ). Metode Debat. Debat sebagai suatu metode dakwah yang pada dasarnya mencari kemenangan, dalam arti menunjukkan kebenaran dan kehebatan Islam. Dengan kata lain, debat adalah mempertahankan pendapat dan ideologinya agar pendapat dan ideologinya itu diakui kebenarannya dan kehebatannya oleh musuh (orang lain). ${ }^{32} 4$ ). Metode Percakapan Antar Pribadi (Percakapan Bebas). Percakapan antar pribadi atau individual conference adalah percakapan bebas antara seseorang da'i atau mubalighh dengan individu-individu sebagai sasaran dakwahnya. Percakapan pribadi bertujuan untuk menggunakan kesempatan yang baik di dalam percakapan atau mengobrol untuk aktivitas dakwah. ${ }^{33}$ 5). Metode Demonstrasi. Demonstrasi maksudnya adalah berdakwah dengan cara memperlihatkan

\footnotetext{
${ }^{29}$ Asmuni Syukir, Dasar-Dasar..., h. 103.

30Ibid., h. 104.

${ }^{31}$ Ibid., h. 124.

${ }^{32}$ Ibid., h. 142.

33Ibid., h. 145.
} 


\section{$\Delta L-n i s h \exists \bar{\Delta} h$,Vol. 11 No. 1, Januari-Juni 2015: 67-104}

suatu contoh, baik berupa benda, peristiwa, perbuatan dan sebagainya dapat dinamakan bahwa seorang da'i yang bersangkutan menggunakan metode demonstrasi. Artinya suatu metode dakwah, di mana seorang da'i memperlihatkan sesuatu atau mementaskan sesuatu terhadap sasarannya (massa), dalam rangka mencapai tujuan dakwah yang dia inginkan. ${ }^{34} 6$ ). Metode Dakwah Rasulullah. Metode dakwah Rasul maksudnya adalah metode yang digunakan Rasul ketika berdakwah di masa awal beliau diangkat menjadi Rasul hingga wafat. Di antara metode dakwah Rasul adalah: a). Dakwah di bawah tanah. Maksudnya adalah berdakwah secara sembunyi-sembunyi. Hal ini disebabkan kondisi yang tidak memungkinkan untuk berdakwah secara terang-terangan. b). Dakwah secara terang-terangan. c). Dakwah politik pemerintah. Maksudnya adalah dakwah dengan menggunakan kekuasaan. Ketika Nabi berkuasa di Madinah, dakwah secara politis ini cukup efektif mengajak orang untuk bergabung. d). Dakwah dengan surat menyurat. e). Dakwah dengan perang. Perang adalah metode dakwah Rasulullah yang paling akhir, bila sudah tidak ada lagi jalan lain yang ditempuh. ${ }^{35}$ 7). Pendidikan dan Pengajaran Agama. Pendidkan dan pengajaran dapat pula dijadikan sebagai metode dakwah. Sebab dakwah dapat diartikan sebagai dua sifat, yakni bersifat pembinaan melestarikan dan membina agar tetap beriman) dan pengembangan (sasaran dakwah). Hakikat pendidikan agama adalah penanaman moral beragama kepada anak. Sedangkan pengajaran agama adalah memberikan pengetahuan-pengetahuan agama kepada anak. Antara aktivitas pengajaran agama dan pendidikan agama, keduanya saling berkaitan bahkan pengajaran merupakan alat perantara pendidikan, sehingga istilah itu sering hanya disebut dengan pendidikan. ${ }^{36}$ 8). Mengunjungi Rumah (Shilaturrahmi). Metode dakwah ini sangat efektif

\footnotetext{
${ }^{34}$ Ibid., h. 146.

${ }^{35}$ Ibid., h. 151-157.

36Ibid., h. 157.
} 
Fahmi Riady, Pola Dakwah Nahdlatul Ulama di Kota Banjarmasin

dalam rangka mengembangkan maupun membina umat Islam. Dan metode ini juga sering dilakukan oleh para da'i agama lain, sebab metode ini murah, mudah, dan efektif. ${ }^{37}$

d. Media Dakwah

Media dakwah maksudnya adalah segala sesuatu yang dapat dijadikan sebagai alat (perantara) untuk mencapai suatu tujuan dakwah yang telah ditentukan. Media dakwah ini dapat berupa barang (material), orang, tempat, kondisi tertentu dan sebagainya. Dalam arti sempit media dakwah dapat diartikan sebagai alat bantu dakwah, atau yang populer di dalam proses belajar mengajar disebut dengan alat peraga. Media ini digunakan sebagai penunjang tercapainya tujuan. Oleh karena itu tanpa media dakwah pun, dakwah masih sangat bisa berjalan dan mencapai tujuan secara maksimal. ${ }^{38}$ Hamzah Ya'qub menyebutkan ada lima macam media dakwah: 1). Lisan, yang termasuk kategori ini adalah khutbah, pidato, ceramah, diskusi, seminar, musyawarah, nasehat, pidato, radio, ramah-tamah, obrolan secara bebas, yang kesemuanya itu menfungsikan lisan atau suara. 2). Tulisan, apa yang dilakukan dengan perantara tulisan, seperti buku, majalah, surat kabar, buletin, kuliah tertulis, iklan, borsur, spanduk, dan lain-lain. 3). Lukisan, berupa gambar hasil seni, baik seni lukis, foto, film, dan lain-lain yang serupa. 4) Audio visual, bentuk tayangan yang dapat dilihat dan didengar. Bentuk ini mengambil rupa seperti televisi, sandiwara, ketoprak, wayang, dan lain sebagainya. 5) Akhlak, yaitu bentuk laku mulia nyata yang dapat rasakan kebaikannya. ${ }^{39}$

Asmuni Syukir menyebutkan beberapa media dakwah yang sedikit berbeda dengan apa yang disebutkan oleh Hamzah Ya'qub. Di antara media dakwah menurut Asmuni Syukir adalah: 1). Lembaga-lembaga Pendidikan Formal, 2). Lingkungan Keluarga, 3). Organisasi-organisasi

\footnotetext{
${ }^{37}$ Ibid., h. 160.

${ }^{38}$ Ibid., h. 164.

${ }^{39}$ Hamzah Ya'qub, Publisistik Islam..., h. 48.
} 


\section{$\Delta L-n i s h \exists \bar{\Delta} h$,Vol. 11 No. 1, Januari-Juni 2015: 67-104}

Islam, 4). Hari-hari Besar Islam, 5) Media Masa, yang di antaranya: radio, televisi, surat kabar dan majalah, dan seni budaya. ${ }^{40}$

Sementara Hafi Anshari membagi media/alat dakwah menjadi dua, pertama yang berbentuk materi (benda) seperti radio, televisi, pengeras suara, dan lain-lain, dan yang kedua adalah yang berbentuk immateri (bukan benda), seperti penguasaan bahasa, pencegahan (preventif), represif (pengetatan) dan lain-lain. ${ }^{41}$

\section{Pola Pelaksanaan Dakwah}

Dilihat dari pola pelaksanaannya, dakwah dapat dibagi menjadi: 1). dakwah bil lisān, 2). dakwah bil hậl, dan 3). dakwah bil kitābah. Dakwah bil lisān adalah penyampaian informasi atau pesan dakwah melalui lisan (ceramah atau komunikasi langsung antara subyek dan obyek dakwah). Dakwah jenis ini akan menjadi efektif bila disampaikan berkaitan dengan hari ibadah seperti khutbah Jumat atau khutbah hari Raya, kajian yang disampaikan menyangkut ibadah praktis, konteks sajian terprogram, disampaikan dengan metode dialog dengan hadirin. Dakwah bil hăl adalah adalah dakwah yang mengedepankan tindakan atau perbuatan nyata. Hal ini dimaksudkan agar si penerima dakwah mengikuti jejak dan hal ikhwal si da'i (juru dakwah).

Dakwah jenis ini mempunyai pengaruh yang besar pada diri penerima dakwah. Pada saat pertama kali Rasulullah tiba di kota Madinah, beliau mencontohkan dakwah bil-hāl ini dengan mendirikan Masjid Quba, dan mempersatukan kaum Anshor dan kaum Muhajirin dalam ikatan ukhuwah Islamiyah. Kemudian dakwah bil kitābah atau dakwah bi al-tadwin adalah dakwah yang dilakukan melalui tulisan, baik dengan menerbitkan kitab-kitab, buku, majalah, internet, koran, dan tulisan-tulisan yang mengandung pesan dakwah. Keuntungan lain dari

${ }^{40}$ Asmuni Syukir, Dasar-Dasar..., h. 168-179.

${ }^{41}$ M. Hafi Anshari, Pemahaman..., h. 177. 
dakwah model ini adalah bahwa tulisan tidak akan menjadi musnah meskipun sang dai, atau penulisnya sudah wafat. ${ }^{42}$

Ketiga pola dakwah yang tersebut di atas merupakan ringkasan dari seluruh aktivitas dakwah para da'i yang bermacam-macam, baik bersifat individu atau berjama'ah dalam suatu organisasi. Istilah bil lisān merupakan istilah yang sangat fleksibel, dapat menampung seluruh aktivitas dakwah yang bersifat verbal. Karena itu apapun media yang digunakan oleh para da'i, dapat dikembalikan pada bentuk awalnya, apakah secara lisan atau bukan. Apakah ia berupa ceramah, diskusi, siaran via radio, televisi, dan berbagai bentuk lainnya, maka dapat dikembalikan pada bentuk bil lisān ini. Kemudian juga bil hạal, cakupannya seluas dakwah bil lisān. Apapun aktivitas dakwah da'i yang tidak masuk dalam kategori lisan, kecuali dakwah lewat tulisan, maka ia masuk dalam kategori bil hāl. Dakwah dalam bentuk keteladanan, kasih sayang, perbuatan nyata, mendirikan panti-panti, mendirikan mesjid, sekolah-sekolah yang orientasinya mengajak pada suatu kebaikan didasarkan oleh anjuran Allah dan kenabian, maka masuk dalam kategori bil hāl. Apa yang disebut orang dengan dakwah kultural misalnya, yaitu dakwah dengan mempertimbangkan unsur-unsur budaya lokal, selama tidak dengan tegas mengarah kepada kemusyrikan, jika setelah diidentifikasi aktivitasnya, maka dapatlah ia masuk ke dalam kategori ke dua ini. Terakhir adalah dakwah bil kitabāh, atau biasa juga disebut dengan dakwah bi al-tadwin atau dakwah bil qalam adalah aktivitas dakwah yang dilakukan dengan media tulisan. Pemikiran-pemikiran yang bersifat mengajak pada kebaikan yang diajarkan oleh agama, baik itu

42 Di dalam Wikipedia disebutkan ada dakwah bil fard, dakwah bil hikmah, dakwah bil lisan, dakwah bil hal, dan dakwah bi al-tadwin atau bil kitabah. Namun terkait dengan dakwah fard dan dakwah bil hikmah, pada tulisan terdahulu, kedua mode dakwah ini masuk dalam kategori metode dakwah. Karena itu, pada pembahasan pola pelaksanaan dakwah, tim penulis hanya memasukkan tiga pola pelaksanaan, yaitu dakwah bil lisan, dakwah bil haal, dan dakwah bil al-tadwin atau bil kitabah. http://id.wikipedia.org, Dakwah (15 November 2010). 


\section{$\Delta L-\cap i s h \exists \bar{\Delta} h$,Vol. 11 No. 1, Januari-Juni 2015: 67-104}

tertuang dalam media buku, surat kabar, majalah, pamlet, jurnal, dan lain sebagainya, dapatlah ia dimasukkan dalam kategori bil kitabah. Dakwah dalam bentuk kitabah merupakan ciri khas dakwah modern. Di sini seorang penda'i dapat menuangkan pikiran-pikirannya secara santai dalam waktu yang tidak berbatas, sehingga dapat menerapkan strategistrateginya dengan baik. Di dunia maya, dakwah dalam model ini banyak diterapkan. Banyak situs-situs dakwah dengan jutaan pengunjung, sebut saja misalkan: MyQur'an.com, situs ini merupakan portal Islam yangvmemiliki banyak link dan sumber informasi tentang aspek kehidupan umat Islam. Situs tersebut dilengkapi dengan fasilitas pencarian ayat-ayat Alquran dan hadits. Informasi tentang rukun Islam pun tersedia. Forum diskusi online, chatroom, dan webmail. Ada lagi situs-situ lain yang serupa seperti Ukhuwah.or.id, MoslemWorld.co.id, IndoHalal.com, dan lain-lain. Hanya saja, dakwah model ini memerlukan keterampilan berbahasa yang baik. Oleh karena itu, dakwah model terakhir ini juga merupakan ciri khas dakwah para intelektual muslim yang menyebarkan pemahaman-pemahaman keagamaannya melalui tulisan dalam wadah yang beragam.

\section{Hasil Penelitian}

\section{Sejarah Organisasi Nahdlatul Ulama di Kota Banjarmasin}

Pada tanggal 31 Januari 1926 (bertepatan 16 Rajab 1344H) di Kampung Kertopaten, Surabaya, lahir sebuah organisasi masyarakat (ormas) Islam, yang bernama Nahdlatul Ulama atau NU, yang arti harfiahnya adalah Kebangkitan para Ulama. ${ }^{43}$ Organisasi ini diprakarsai oleh sejumlah ulama terkemuka di Jawa. Sejarah mencatat, jauh sebelum NU lahir dalam bentuk organisasi (jam'iyyah), NU sudah ada dalam bentuk jama'ah (community) yang beraktivitas dalam ranah sosial

\footnotetext{
${ }^{43}$ Muhamad Mukhsin Jamil, dkk., Nalar Islam Nusantara...h. 277.
} 
Fahmi Riady, Pola Dakwah Nahdlatul Ulama di Kota Banjarmasin

keagamaan dan memiliki karakteristik tersendiri. Lahirnya organisasi NU dapat dikatakan sebagai penegasan formal dari mekanisme informal para ulama yang sefaham sepaham yang memegang empat madzhab fiqih untuk memperluas cakupan wilayah pengabdian. ${ }^{44}$

Organisasi NU berkembang cukup pesat, karena NU sudah memiliki jaringan luas melalui pesantren yang tidak hanya ada di Jawa, tetapi juga sampai Sumatera, Kalimantan, Sulawesi, dan Nusa Tenggara Barat. Jaringan ini sudah berlangsung lama, di antaranya karena pertemanan saat menimba ilmu di pesantren, atau ketika bersama-sama belajar di Makkah.

Demikianlah, setelah NU didirikann tanggal 31 Januari 1926, delapan bulan kemudian diadakan Muktamar NU I di kota yang sama tanggal 21-23 September 1926 (14-16 Rabiul Awal 1345 H). Muktamar ini dihadiri oleh sekitar 216 orang utusan dari berbagai daerah di Indonesia, yang di antaranya terdapat sekitar 170 orang alim ulama seperti: K.H. Abdullah dari Palembang, J.H. Abu Bakar dari Kalimantan dan Tuan Guru Haji Abdul Qadir Hasan dari Martapura (Kalimantan Selatan). Dari 170 alim ulama tersebut, terdapat 93 orang kyai dari Jawa dan Madura. ${ }^{45}$

Kehadiran Tuan Guru Haji Abdul Qadir Hasan pada Muktamar yang diselenggarakan di Hotel Muslimin jalan Peneleh Surabaya tersebut memiliki arti penting bagi kelahiran Jam'iyyah NU di Kalimantan Selatan. Karena pada tahun 1928, Guru Haji menggagas berdirinya NU. Ulama yang di Martapura dikenal dengan panggilan "Guru Tuha" telah belajar

\footnotetext{
${ }^{44}$ Muhamad Mukhsin Jamil, dkk., Nalar Islam Nusantara...,h. 280.

${ }^{45}$ Choirul Anam, Pertumbuhan dan Perkembangan Nahdlatul Ulama (Sala: Jatayu, 1985), h. 74.
} 


\section{$\Delta L-n i s H \exists \bar{\Delta} H$, Vol. 11 No. 1, Januari-Juni 2015: 67-104}

ilmu agama di Pondok Pesantren Tebu Ireng Jombang pimpinan Hadratus Syeikh K.H. Hasyim Asy'ari dan Pondok Pesantren Salafiyah Bangkalan Madura pimpinan Kyai Kholil, dan juga di Madrasah Saulatiah Makkah Saudi Arabia. Di Martapura beliau belajar dengan Tuan Guru Haji Abdurrahman, atau yang dikenal dengan Haji Adu, dan Tuan Guru Haji Kasyful Anwar, pendiri Madrasah Darussalam Martapura, yang sekarang lebih dikenal dengan Pondok Pesantren Darussalam Martapura.

Kelahiran NU di Kalimantan Selatan mendapat dukungan dari pimpinan Madrasah Darussalam Martapura, yaitu Tuan Guru Haji Kasyful Anwar. Ada beberapa alasan mengapa NU diterima di Martapura: pertama, karena paham Ahl al-Sunnah wa al-Jama'ah sudah demikian mengakar pada kehidupan masyarakat Banjar. Kedua, pendirinya adalah tokoh agama setempat yang cukup dikenal, khususnya di Martapura. Ketiga, adanya dukungan dari para ulama.

Dalam kurun waktu 14 tahun, atau sampai dengan kedatangan tentara Jepang di Indonesia (1942), jumlah anggota NU di Kalimantan Selatan mencabai 2000 orang. Akan tetapi selama pendudukan Jepang, Jamiyyah NU cabang Martapura mengalami kemunduran. Pembentukan Jam'iyyah NU di Martapura kemudian disusul dengan berdirinya majelis konsul dan beberapa cabang NU di wilayah Kalimantan. Majelis Konsul NU pertama kali berdiri di Barabai pada tahun 1933. Pendiri dan sekaligus pimpinan Majelis Konsul NU tersebut adalah H. Sulaiman Kurdi.

Dalam perkembangannya Majelis Konsul NU di Barabai dipindah ke Banjarmasin sekitar tahun 1950-an. Sementara itu di Kota Barabai sendiri telah berdiri cabang NU selai di Haruyan (Labuan Amas Selatan) dan di Limbar (Batang Alai Selatan). NU masuk ke Haruyan sekitar tahun 1934 bersamaan dengan dibukanya madrasah NU yang pada waktu itu 
Fahmi Riady, Pola Dakwah Nahdlatul Ulama di Kota Banjarmasin

gurunya didatangkan dari pulau Jawa. Delapan belas tahun kemudian (1952), cabang NU di Haruyan menjadi Cabang Partai NU Haruyan. Begitu juga Jam'iyyah NU di Limbar yang berubah menjadi Cabang Partai NU pada tahun 1953. Beberapa tahun setelah berdiri NU di Martapura, Cabang NU di Banjarmasin juga berdiri (sekitar tahun 1930an). Cabang NU Banjarmasin diketuai oleh H.Gusti Umar dan berkantor di rumah beliau sendiri Jalan Sungai Mesa Banjarmasin. Cabang NU berikutnya yang berdiri setelah itu adalah NU di Negara, yang didirikan oleh Tuan Guru Haji Muhammad Jasin sekitar tahun 1935-an. Pada tahun 1939, cabang Negara menjadi tuan rumah Konferensi Daerah. Selain di Negara, NU juga berdiri di Kandangan, yang dipelopori oleh Tuan Guru H.M. Arsyad, Tuan Guru H. Abdul Wahab, dan Tuan Guru H. Iberahim. Cabang yang berbasis di desa Bamban ini berdiri sekitar tahun 1936, diketuai oleh H. Zuhri.

Delapan tahun setelah berdirinya NU di Kalimantan Selatan, diadakan Muktamar NU XI di Banjarmasin (Juni 1936). Muktamar NU XI bertempat di sebuah rumah bertingkat dua di tepi sungai Martapura (persisnya di samping kiri langgar Hinduan Jalan Sungai Mesa Banjarmasin). Selain dihadiri dan dibuka oleh pimpinan Hoop Bestuur NU (K.H. Wahab Chasbullah), muktamar ini juga diikuti oleh utusanutusan NU dari luar Kalimantan dan pimpinan Majelis Konsul dan beberapa cabang/majelis wakil cabang/ranting NU wilayah Kalimantan sendiri. Utusan muktamar, terutama yang berasal dari luar Kalimantan, ditempatkan di rumah Haji Gusti Umar yang pada waktu itu juga berfungsi sebagai kantor NU Cabang Banjarmasin. Salah satu keputusan yang terpenting adalah pengajuan mosi kepada pemerintah Hindia Belanda untuk membatalkan keinginan mereka mengadakan pencatatan 


\section{$\Delta L-n i s H \exists \bar{\Delta} H$, Vol. 11 No. 1, Januari-Juni 2015: 67-104}

sukarela perkawinan bagi orang-orang yang hak perkawinannya belum ditetapkan dalam undang-undang. Kemudian dalam masalah agama, yang menjadi keputusan muktamar adalah tentang hukum memberi salam oleh kaum laki-laki kepada perempuan. Dalam muktamar ini, beberapa organisasi seperti Musyawarah Thalibin dan Hidayatul Islamiyah menyatakan bergabung dengan Jam'iyyatul NU. Dengan penggabungan tersebut, jumlah anggota NU semakin bertambah, dab berdiri beberapa cabang/Majelis Wakil Cabang/ranting NU yang baru di Kalimantan Selatan, yang pada waktu itu disebut Keresidenan Borneo Selatan atau Zuider Afdeling van Borneo dengan ibu kota Banjarmasin, yang terdiri dari Propinsi Kalimantan Selatan (luas $37.660 \mathrm{~km}^{2}$ ) dan Propinsi Kalimantan Tengah $\left(152.600 \mathrm{~km}^{2}\right) .{ }^{46}$ Adapun cabang NU yang baru pasca muktamar adalah Cabang NU di Kelua, Cabang NU di Alabio dan Cabang NU di Ampah. Pada tahun 1938, cabang NU Kelua menjadi tuan rumah Konferensi Daerah. Sebagai tuan rumah, cabang NU ini diperkirakan mempunyai anggota cukup banyak pada saat itu dan terus bertambah setelah Konferensi tersebut. Tetapi kemudian, pada tahun 1950-an, anggota NU cabang Kelua hanya tinggal 11 orang, karena para anggotanya telah menjadi anggota Partai Masyumi sejak pendudukan Jepang. Dari Kelua, NU kemudian masuk dan berkembang ke daerah lainnya di Kabupaten Tabalong seperti ke Tanjung dan Muara Uya.

Dari tahun 1928 sampai tahun 1951, NU masih berupa Jam'iyyah al-Diniya al-Islamiyah (Organisasi sosial keagamaan), tetapi kemudian menjadi partai politik (Partai NU) sejak tahun 1952.

${ }^{46}$ Pemerintah Provinsi Daerah Tingkat 1 Kalimantan Selatan, Sejarah Perjuangan Rakyat Menegakkan Kemerdekaan Republik Indonesia di Kalimantan Selatan (Periode 1945-1949) (Banjarmasin, ttp, 1994), h. 4. 
Fahmi Riady, Pola Dakwah Nahdlatul Ulama di Kota Banjarmasin

Konsekuensi perubahan ini, Majelis Konsul NU di Banjarmasin (majelis konsul NU ke-2) yang ketika itu diketuai oleh $\mathrm{H}$. Saadiat berubah menjadi Majelis Konsul Partai NU Kalimantan Selatan. Sejalan dengan perubahan status organisasi (dari Jam'iyyah NU menjadi Partai NU), Majelis Konsul NU di Barabai ditiadakan, kecuali di tingkat cabang. Sebagai penggantinya didirikan Majelis Konsul Partai NU Wilayah Kalimantan Selatan di Banjarmasin. Majelis Konsul yang baru ini telah dibentuk melalui Rapat Kerja Daerah NU di Kantor Kerapatan Qadhi Banjarmasin 914 Desember 1952. Enam bulan setelah terbentuk Majelis Konsul Partai NU Wilayah Kalimantan Selatan, tanggal 22-23 Juni 1953 diadakan Konferensi Kerja Partai NU se-Kalimantan Selatan di Gedung NU Jalan Kelayan B Banjarmasin. Konferensi yang dihadiri oleh Sekjen PBNU, K.H. Ideham Chalid ini membicarakan urusan intern organisasi dan pelaksanaan pemilihan umum 1955. Kemudian pada tanggal 23-25 Agustus 1953 diadakan Konferensi Kerja Partai NU se-Kalimantan Selatan ke-2 di Gedung Normal Islam dan Gedung Musjawarah Pasar Amuntai. Konferensi ini dinamakan Konferensi Akbar, sesuai dengan hasil keputusan Konferensi Kerja ke-1 di Banjarmasin. Setelah Konferensi Akbar di Amuntai, diadakan rapat kerja Partai NU di Banjarmasin pada tanggal 31 Desember 1953. Dalam rapat kerja yang dihadiri oleh Sekjen PBNU, K.H. Ideham Chalid, diputuskan bahwa Majelis Konsul yang baru dibentuk setahun yang lalu (1952) akan direshuffle. Namun reshuffle ini tidak mendasar, karena hanya merombak sebagian kecil saja, yang di antaranya adalah penambahan kordinator konsul dan anggota serta pergantian ketua. ${ }^{47}$

\footnotetext{
${ }^{47}$ Ahdi Makmur, dkk., "Sejarah Perkembangan Nahdlatul Ulama di Kalimantan Selatan (1926-1984)," dalam Jurnal Penelitian: Media Komunikasi Penelitian Agama dan
} 


\section{$\Delta L-n i s H \exists \bar{\Delta} H$, Vol. 11 No. 1, Januari-Juni 2015: 67-104}

Sejak kepemimpinan yang baru, terjadi perubahan kepengurusan organisasi tingkat daerah dari Majelis Konsul Partai NU Kalimantan Selatan menjadi Pengurus Wilayah Partai NU (PWPNU) Kalimantan Selatan. Perubahan nama ini sejalan dengan terjadinya perubahan nama kepengurusan di tingkat pusat, yaitu sejak dipindahkannya pusat pimpinan NU dari Surabaya, yang ketika itu bernama "Hoop Bestuur Nahdlatoel Oelama," ke Jakarta dengan menggunakan nama "Pengurus Besar Nahdlatul Ulama (PBNU)."

PWNU Pada awalnya berkantor di Jalan Sungai Mesa, menempati rumah Gusti Umar. Karena rumah ini juga menjadi kantor cabang Partai NU Banjarmasin, kemudian kantornya dipindah ke rumah H. Sahal di samping langgar Hinduan. Baru pada tahun 1960-an PWNU pindah kantor karena pada waktu maraknya demonstrasi menentang pemerintah Orde Lama dan menuntut pembubaran PKI (1966) PWNU sudah berkantor di Jalan Pangeran Samudera seberang Mesjid Noor, menempati gedung milik H. Amir Hasan pengusaha karet asal Amuntai yang juga bekerja di Percetakan Bintang Borneo Banjarmasin.

PWNU masa kepemimpinan H. Riduan Sjahrani bekerja sampai tahun 1956, setahun setelah diadakan Pemilu pertama di Indonesia (1955). Sejak tahun 1957, PWNU Kalimantan Selatan diketuai oleh M. Arthum Husien (masa khidmat 1957-1960). Menyusul Konferensi Akbar di Amuntai, Konferensi Kerja ke-3 dilaksanakan di Haruyan (11-13 Agustus 1957) yang kemudian diikuti oleh Konferensi Kerja berikutnya secra berturut-turut diadakan di Banjarmasin (25-26 Juni 1960, 7-9 September 1963), tahun 1967 dan tahun 1971).

Kemasyarakatan (Banjarmasin: Pusat Penelitian IAIN Antasari, 2000), h. 26. 
Fahmi Riady, Pola Dakwah Nahdlatul Ulama di Kota Banjarmasin

Pada Konferensi Kerja Partai NU Wilayah Kalimantan Selatan di Banjarmasin (22-23 Pebruaru 1960), tidak dihadiri oleh utusan PBNU. Walaupun demikian, dalam konferensi tersebut telah berhasil memilih pengurus PWNU Kalimantan Selatan yang baru (masa khidmat 19611964), yang kepengurusannya diketuai oleh H. Abdulganie Madjedie. Pengurus PWNU masa khidmat 1965-1968 disahkan oleh PBNU melalui SK No.229/Tanf?Peng/IX/65 tanggal 18 Jumadil Awal 1385 H/15 September 1965M.

Kepengurusan demi kepengurusan PWNU Kalimantan Selatan terus barganti. Pada masa khidmat 1969-1972, PWNU diketuai oleh H. Abdurrasyid Nasar. Pada saat H. Abdurrasyid Nasar menjadi ketua PWNU, kantornya pindah ke jalan Hasanuddin HM. Kedudukan H. Abdurrasyid Nasar sebagai ketua Tanfidziah kemudian diganti oleh $\mathrm{H}$. Abdulganie Madjedie kembali. Namun kepemimpinan H. Abdulganie Madjedie tidak sampai berakhir kaena beliau meninggal dunia tahun 1979. Pada masa kepemimpinan H. Abdulganie inilah Partai NU berfusi ke dalam Partai Persatuan Pembangunan (PPP) pada tahun 1973, ${ }^{48}$ sehingga keterlibatan warga nahdliyyin di Kalimantan Selatan dalam aktivitas politik untuk periode-periode berikutnya sudah tidak lagi melalui Partai NU, tetapi melaui PPP dan Golkar. ${ }^{49}$

Karena H. Abdulganie Madjedie meninggal pada tahun 1979, masa kepemimpinan beliau diteruskan oleh H.M.Imansyah sampai terbentuk kepengurusan baru yang diketuai oleh $H$. Safriansyah, BA (masa khidmat 1984-1986). Pada masa kepemimpinan H. Safriansyah,

\footnotetext{
${ }^{48}$ Ibid.,h. 27.

${ }^{49}$ Ibid., h. 29.
} 


\section{$\Delta L-n i s H \exists \bar{\Delta} H$, Vol. 11 No. 1, Januari-Juni 2015: 67-104}

BA, NU menyatakan dirinya kembali ke khittah 1926 berdasarkan keputusan hasil muktamar NU XXVII di Situbondo tahun 1984. Meskipun NU telah kembali ke khittah 1926, beberapa pimpinan PWNU Kalimantan Selatan masih aktif dalam PPP termasuk ketuanya H.Safriansyah,BA. Keputusannya untuk tetap aktif di PPP, menyebabkan jabatan ketua tanfidziyah PWNU Kalimantan Selatan menjadi kosong. Namun kemudian pada tahun 1986 disusun kembali kepengurusan NU Kalimantan Selatan yang baru, yang diketuai oleh H.M. Saleh Fauzie, PWNU Kalimantan Selatan diketuai secara berturut-turut oleh Dr. H. Zurkani Yahya (1991-1995), dan berakhir oleh Drs. H.Tabrani Baseri (1996-2002), Drs. H. Rusdiansyah Asnawi, S.H. (2003-2007), dan terakhir hingga sekarang adalah Drs. H. Syarbani Hairi,M.Si. (20072012). ${ }^{50}$

\section{Pola Dakwah Organisasi Nahdlatul Ulama di Kota Banjarmasin}

Seperti halnya organisasi Muhammadiyah, pola dakwah Nahdlatul Ulama juga dapat dikategorikan dalam dua bentuk, Pertama, dakwah yang bersifat internal dan kedua adalah dakwah yang bersifat eksternal. Dalam internal NU dalam arti konsolidasi antar pengurus biasaya dilakukan atas kerjasama Pengurus Cabang dengan Pengurus Majelis Waki Cabang. Media yang dilakukan adalah shilaturrahmi. Di kalangan warga pengurus NU Kota Banjarmasin, seperti yang dijelaskan Bapak Emroni, dikenal sebuah sarana kumpul bulanan yang dinamakan dengan "Lailatul Ijtima," atau yang berarti Malam Bertatap Muka. Lailatul Ijtima ini biasa dilaksanakan menurut penanggalan Hijriyah pada saat bulan

\footnotetext{
${ }^{50}$ Ibid., h. 19-32.
} 
Fahmi Riady, Pola Dakwah Nahdlatul Ulama di Kota Banjarmasin

purnama. Dalam penanggalan Hijriyah, bulan purnama ditengarai bertepatan antara tanggal 14, 15, dan 16. Acara ini dilaksanakan di rumah-rumah Pengurus Wakil Cabang yang tersebar di setiap kecamatan.

Dalam acara Lailatul Ijtima, biasa diisi dengan tahlilan, penyampaian informasi terkait dengan jam'iyyah, arah dan strategi yang diterapkan NU, sharing permasalahan, dan lain-lain. Adapun yang tidak pernah tertinggal dalam shilaturrahmi bulanan adalah ceramah agama yang biasa diisi oleh pengurus besar NU Wilayah Kalimantan Selatan. Dari sekian pertemuan dalam Lailatul Ijtima, tecatat beberapa Tokoh NU yang mengisi acara pengajian tersebut, yang di antaranya: K.H. Ahmad Sufyan, beliau adalah Rais Syuriah NU Kalimantan Selatan. K.H. Hadrawi H.K., juga salah satu Rais Syuriah NU Kal-Sel. K.H. Bahrul Ilmi, K.H. Syamsul Rahman, Drs. H. Ahmad Nawawi, M.Si., Prof. Dr. H. Asmaran AS, M.A., Prof. Dr. H. Fahmi Arief, M.A., Prof. Dr. H. Abdul Hafiz Anshari AZ, M.A., Drs. H. Murdjani Sani, M.Ag., Dr. H. Saifullah Abdussamad, Lc.,M.A., K.H. Abdul Gaffar Syukur,B.A., dan K.H. Abdul Qadir Syukur,L.M.L.

Menurut Sekretaris Wilayah NU, Bapak Sarmiji Asri, S.Ag.,M.H.I, aktivitas konsolidasi antar pengurus tersebut memberikan pengaruh cukup berarti, setidaknya dalam mempererat hubungan kekeluargaan antar pengurus NU Kota Banjarmasin. Di samping aktivitas tersebut di atas, Pengurus Cabang NU Kota Banjarmasin juga melaksanakan beberapa kegiatan dalam rangka pembekalan pengurus, seperti latihan pidato, latihan menjadi khatib, latihan merawat jenazah, arisan, yasinan, dan lainlain.

NU Kota Banjarmasin secara struktural memang tidak mempunyai tempat-tempat khusus dalam membina hubungan dengan masyarakat. 
Karena itu masyarakat NU bersifat cair, tidak terkelola dengan baik. Namun bukan berarti dalam hal ini NU dan masyarakatnya lepas sama sekali tanpa ada sarana pengikat. Sebagaimana tersebut di atas, dalam pembangunan tempat-tempat peribadatan, organisasi NU tidak pernah terlibat secara langsung, dalam arti instruksional. Berdasarkan inisiatif masyarakat sendiri, mereka membangun mesjid-mesjid atau mushallamushalla yang dalam praktik peribadatannya memiliki karakteristik NU. Di tempat seperti inilah NU menyebarkan dakwahnya. Memang ada ujaran seperti ini, bahwa selain Mesjid atau Mushalla Muhammadiyah, semua tempat peribadatan itu adalah milik NU. Benar memang, tetapi bukan dalam arti kepemilikan, melainkan dalam arti afiliasi, atau kecenderungan masyarakat untuk bergabung ke organisasi ini. Mesjid Nurul Amilin, Jalan Kelayan B, Banjarmasin Selatan, Mesjid al-Taqwa Jalan Ahmad Yani, Banjarmasin Timur, Mesjid Kanas Jalan Alalak Utara, Banjarmasin Utara, Mesjid Jami' Teluk Dalam, Jalan Sutoyo, Banjarmasin Barat, Mesjid alKhair Jalan Sutoyo, Banjarmasin Tengah, Mesjid al-Anshor Cempaka Besar, Banjarmasin Barat, Mesjid al-Syafa'ah Kuripan, Banjarmasin Tengah, Mesjid al-Raudhah Jalan Ratu Jaleha, Banjarmasin Timur, Mesjid al-Mubarak Jalan Pekapuran Raya, Banjarmasin Timur, dan Mesjid Raudhatul Istiqamah Jalan Pekapuran Raya, Banjarmasin Timur, adalah contoh dari beberapa mesjid yang berafiliasi ke organisasi NU. Sehingga di mesjid-mesjid seperti ini tokoh-tokoh NU memberikan penjelasan keagamaan pada warganya.

Mereka yang namanya tersebut di atas, yaitu yang sering mengisi pada Lailatul Ijtima adalah nama-nama yang sudah familiar dalam berdakwah di kalangan masyarakat NU. Selain mereka itu ada lagi yang lain, di antaranya adalah: Bapak Sarmiji, S.Ag, M.H.I., Drs. Emroni, 
Fahmi Riady, Pola Dakwah Nahdlatul Ulama di Kota Banjarmasin

M.Ag., Humaidi, Asikin Nor, H. M. Husni Nurin, M.H., K.H. Muhammad Sa'dillah, K.H. Waini Hambali, K.H. Abdussamad Sulaiman Lc., Drs. H.M. Kasim Hamid, Drs. K.H. Ibrahim Hasani, Drs. H. Said Agil Assegaf, Drs. H. Ahmad Zamani, M.Ag., Drs. K.H. Taberani Baseri.

Materi yang disampaikan pada jama'ah dalam ceramah-ceramah keagamaan di antaranya adalah fiqih, tasawuf (akhlak), tafsir Alquran, Tauhid, dan hal-hal yang bersifat umum. Di Mesjid Raudhatul Istiqamah, sebuah mesjid yang terletak di dalam Pondok Pesantren kelolaan warga NU pengajian khusus membahas kitab-kitab keagamaan. Pengajian di Mesjid tersebut biasa dipandu oleh Drs. H. Husni Tabsyir dan Ust. Abdul Muis Basri.

Walau kegiatan ceramah seperti tersebut di atas bukan dari inisiatif organisasi, tapi boleh kiranya dipandang sebagai dakwah organisasi di kalangan warga Nahdliyin. Kegiatan lain yang bernilai dakwah, termasuk sebagai sarana konsolidasi antar sesama warga adalah kegiatan tahlilan. Tahlilan merupakan acara yang biasa dilakukan dalam peristiwa kematian. Acara ini biasa dilakukan pada malam hari. Pada hari pertama sesudah mayit dikuburkan. Pada hari ketiga, hari ketujuh, ke duapuluh lima, ke empat puluh, ke seratus, dan sesudah setahun yang sering dinamakan dengan acara bahaul (satu tahun). Dalam acara memperingati kematian ini biasa acara pokoknya adalah membaca tahlil (kalimat laa ilaaha illallahu dan do'a-do'a) yang dipimpin oleh seorang ustadz, maka karena itu ia dinamakan dengan tahlilan. Dapat dikata, warga NU memiliki hubungan yang erat satu sama lain dikarenakan aktivitas tahlilan ini. Dan inilah yang menjadi ciri khas warga Nahdliyyin dalam beragama. 


\section{$\Delta L-n i s h \exists \bar{\Delta} h$,Vol. 11 No. 1, Januari-Juni 2015: 67-104}

Di samping tahlilan, ada lagi acara-acara yang melingkar seputar kelahiran, perkawinan, dan kematian. Untuk kelahiran, ada acara yang dinamakan dengan akikah atau juga tasmiyah. Meski acara seperti ini merupakan amalan sunnah yang seyoginya dilakukan oleh seluruh umat Islam, namun dalam lingkungan Nahdliyin, terdapat ciri khas tersendiri. Seperti yang diceritakan oleh Bapak Sarmiji Asri, di dalam proses tasmiyah biasa diawali dengan pembacaan ayat Alquran oleh seorang Qari. Kemudian dilakukan acara tasmiyah (pemberian nama bagi bayi), doa tasmiyah, cukur rambut, tapung tawar (memercikkan air ke kepala si bayi yang digendong oleh ayahnya menyusuri setiap hadirin), tahnik (memasukkan benda-benda manis seperti madu, kurma,dll. ke langitlangit mulut si bayi), kemudian diteruskan dengan acara manakib (pembacaan syair tetang riwayat hidup tokoh, seperti Nabi Muhammad, Siti Khadijah, Syekh Abdul Kadir Jaelani, Syekh Saman, dll.), atau jika tidak dengan manakib, biasa dilanjutkan dengan ceramah oleh seorang ustadz.

Acara-acara khas warga Nahdliyin lainnya adalah seperti Maulidan (memperingati kelahiran Nabi Muhmmad). Dalam acara ini ciri khasnya adalah membacakan syair-syair tentang riwayat hidup tokoh agama seperti tersebut di atas yang terdapat di dalam kitab-kitab seperti: al-Barzanji, al-Diba'i, Syaraful Anam, al-Habsyi, al-Azab, dan al-Burdah. Tradisi-tradisi seperti ini sangat manjur dalam mengikat keutuhan warga. Hampir bisa dikatakan, jika tidak ada tradisi-tradisi semacam ini, warga NU akan berai berantakan, tidak memiliki ikatan yang kuat. Karena jika dilihat dari administrasi kepengurusannya, NU Kota Banjarmasin khususnya dapat dikatakan lemah, tidak tertib administrasi. Sebagaimana yang diberitakan Koran Banjarmasinpost tanggal 4 Desember 2010, Drs. 
Fahmi Riady, Pola Dakwah Nahdlatul Ulama di Kota Banjarmasin

H.M. Syarbani Haira,M.Si., selaku Pimpinan Wilayah NU mengatakan, bahwa dalam hal administrasi, NU di Banjarmasin budaya administrasinya tidak bagus.

Sebagaimana tempat-tempat ibadah yang kepemilikannya tidak begitu tegas, dalam arti instruktif dan dibangun oleh organisasi NU, sekolah-sekolah juga demikian. Mulai dari kepengurusan tingkat Cabang di tingkat kota sampai Majelis Wakil Cabang tingkat kecamatan dan Ranting di tingkat kelurahan, organisasi NU tidak memiliki hak kepengurusan akan amal-amal usaha seperti pendidikan. Yang ada hanya atas hasil inisiatif warga Nahdliyin yang mendirikan sekolah atau pondok pesantren dengan afiliasi yang kental pada tradisi NU. Sehingga dapat dikata aset-aset seperti lembaga pendidikan pondok pesantren atau sekolah-sekolah itu merupakan milik individu yang notabene warga NU, dan bukan milik organisasi. Terkait dengan dakwah dalam lapangan pendidikan, ada beberapa yang dapat disebutkan, di antaranya adalah: SMP NU di Pekauman, SMK Otomotif NU di Pekauman. Tk, Ibtidaiyah, dan MTs Dārul Ulūm di Teluk Tiram. TK, Ibtidaiyah, dan MTs Nurul Ulūm di Teluk Tiram. TK dan Ibtidaiyah al-Raudah di Kelayan. TK dan Ibtidaiyah Bābussalām di Kelayan. TK, Ibtidaiyah, MTs, Aliyah alGhazaliah di Cempaka Besar. TK dan Ibtidaiyah Ibnu Katsir di Pekauman. TK, Ibtidaiyah, dan MTs Dārul Huda di Kuin Selatan, dan TK, Ibtidaiyah, dan MTs Nurul Islām Jalan Ahmad Yani.

Dalam kegiatan dakwah secara tertulis, NU Kota Banjarmasin tidak melakukan hal ini. Kalaupun ada, itu bersumber dari distribusi pusat ke daerah. Di antara yang masuk ke daerah adalah Majalah Aula, terbit perbulan. Ada juga koran Duta Masyarakat, terbit perhari, namun tidak semua warga menjadi pelanggannya. Dan tidak semua warga mengetahui 


\section{$\Delta L-n i s H \exists \bar{\Delta} H$, Vol. 11 No. 1, Januari-Juni 2015: 67-104}

keberadaan dua industri berita dari pengurus NU pusat tersebut. Bahkan hasil bahtsul masa'il yang dilakukan oleh Alim Ulama NU, catatannya jarang dimiliki oleh warga. Kegiatan pencerahan dalam bidang kitabah ini memang sangat jarang terlihat. Mungkin pengaruh budaya kurang baca, sehingga hal-hal penting terkait keorganisasian yang diinformasikan melalui media cetak seperti tersebut, jarang mendapat perhatian.

Demikianlah beberapa hal yang dapat diinformasikan terkait pola dakwah yang dikembangkan oleh organisasi NU di Kota Banjarmasin. Banyak mungkin informasi yang tidak dapat disajikan oleh tim peneliti, itu karena beberapa alasan, yaitu kecocokan data dengan masalah yang tengah diangkat. Banyak informasi yang telah digali peneliti, namun karena tidak sesuai, maka data-data tersebut tidak dapat tim peneliti sajikan dalam laporan hasil penelitian.

\section{Analisis Data Pola Dakwah NU di Kota Banjarmasin}

Dakwah sebagaimana yang telah dipahami adalah menyeru atau mengajak. Dalam arti sederhana yaitu mengajak orang yang diseru agar kembali kepada fitrahnya untuk mentaati ketentuan pencipta dengan realisasi amal baik. Ketentuan di sini dapat berarti memenuhi kewajiban dirinya sebagai seorang hamba terhadap Allah dalam konteks peribadatan, atau sebagai seorang manusia yang memiliki tanggung jawab moral terhadap diri dan sesama manusia dalam konteks amal sosial. Dalam berbagai bentuknya, dakwah kadang bersifat individual, dan ada juga yang bersifat komunal, kelompok, atau organisasi. Pada konteks ke dua inilah dakwah menampakkan keseriusannya. Organisasi menunjukkan suatu kematangan dalam meraih suatu tujuan yang besar.

Di Banjarmasin, Organisasi Nahdlatul Ulama. Langkah yang paling mendesak untuk organisasi ini adalah perobakan administrasi 
Fahmi Riady, Pola Dakwah Nahdlatul Ulama di Kota Banjarmasin

secara menyeluruh. Meski di atas kertas organisasi ini memiliki kelengkapan persyaratan sebagai organisasi, hanya saja perlu dibenahi lebih lanjut. Kegiatan seperti Lailatul Ijtima semestinya juga melahirkan ide-ide tentang perubahan dalam tatanan administrasi berorganisasi. Selama ini organisasi Nahdlatul Ulama Kota Banjarmasin masih terjebak dalam kerumitan permasalahan seperti itu. Kadang, jika pimpinan Majelis Wakil Cabang berganti, maka kantornyapun ikut berpindah mengikuti tempat ketua Majelis Wakil Cabangnnya yang baru. Hal ini tentu cukup merepotkan.

Pada hakikatnya dakwah Nahdlatul Ulama secara organisasi dapat dikatakan mandul, karena antara organisasi dengan gerakan di lapangan itu terputus. Apa yang dilakukan oleh tokoh-tokoh Nahdlatul Ulama Kota Banjarmasin sebenarnya bukanlah cerminan organisasi, melainkan cerminan dari tokoh-tokoh itu sendiri. Mulai dari mesjid, amal usaha di bidang pendidikan, dan lain-lain, itu semua berdasarkan inisiatif individu, yang kadang mengaitkannya dengan organisasi, atau hanya sekedar berafiliasi. Karena tidak terlahir dari organisasi inilah maka dampaknya cukup riskan. Pertama, jika menghasilkan untung, tentu larinya ke individu pengelolanya itu sendiri. Kedua, jika rugi, atau ada hal-hal yang dapat menurunkan citra lembaga amal usaha itu, maka otomatis juga akan mencoreng citra organisasi Nahdlatul Ulama. Berbeda halnya jika semua amal usaha itu dikelola oleh organisasi, maka tanggung jawab baik buruknya tergantung pada kematangan organisasi ini dalam mengelolanya.

Namun di balik ketidakberesan ini, organisasi Nahdlatul Ulama Kota Banjarmasin memiliki basis pengikut yang sangat besar, ini disebabkan oleh dakwah kulturalnya yang senantiasa memelihara tradisi. 


\section{$\Delta L-n i s h \exists \bar{\Delta} h$,Vol. 11 No. 1, Januari-Juni 2015: 67-104}

Dengan tradisi seperti tahlilan, muludan, tasmiyahan, dan berbagai hal lain terkait dengan perjalanan hidup manusia; lahir, menikah, meninggal, NU dapat membangun jaringan pengikut yang sangat banyak. Maka sebenarnya dakwah bil hā $/ \mathrm{NU}$ di kalangan akar rumput cukup berhasil. Hanya saja masih mencair dan parsial. Aktivitas-aktivitas seperti tersebut di atas dibina atas dasar kesadaran masyarakat, bukan berawal dari instruksi organisasi.

Maka menyambung mata rantai yang putus ini adalah tugas besar NU dalam mengikat hubungan yang baik dengan jama'ahnya. Mesjidmesjid yang diduga keras berafiliasi perlu ditegaskan, sehingga kegiatankegiatan organisasi dapat ditata dengan baik. Pengajaran keagamaan masyarakat NU melalui majelis taklim mulai disistematiskan. Sehingga tidak ada lagi kesan tumpang tindih, atau saling bertentangan.

Dakwah bil kitabāh, kurang mendapat perhatian. Padahal melalui media ini dakwah yang terputus secara lisan dapat dihubungkan. Visi misi organisasi dan pola pikir dalam menyelesaikan permasalahanpermasalahan keseharian jama'ah dapat disebarluaskan. Buletin, pamlet, dan lain-lain yang serupa, adalah media yang murah untuk memanjangtangani kehendak organisasi agar sampai pada jama'ah. Sehingga melalui media ini langkah penataan organisasi, baik secara administrasi atau kelembagaan mendapat respons yang besar dari masyarakat nahdliyyin. Bisa saja permasalahan dana yang dulunya ditakutkan, setelah adanya pewacanaan hajat yang disampaikan secara sederhana melalui media tertulis, mulai terselesaikan, karena masyarakat bahu membahu membatu untuk keberlangsungan organisasi yang mereka cintai. 
Fahmi Riady, Pola Dakwah Nahdlatul Ulama di Kota Banjarmasin

Adapun dakwah bil lisān, jika dilihat dari sisi organisatoris, maka sebenarnya dakwah bil lisān NU tidak efektif, hanya saja ketika dilihat dari sisi person-person, yang warga NU, maka dakwahnya bisa dikatakan sangat efektif. Ini bisa dilihat dari aktivitas keagamaan NU yang luar biasa. Tentu hal ini tidak dapat dilepaskan dari pengaruh dakwah bil lisan yang diselengarakan oleh tokoh-tokoh keagamaan NU. Kuatnya aktivitas kultural yang kadang juga dinilai sebagai aktivitas keagamaan semisal tahlilan, muludan, haulan, dan pembacaan manakib di berbagai kegiatan keagamaan lebih banyak disponsori oleh mereka-mereka yang tingkat pemahaman keagamaannya baik. Karena yang sering menjadi pemandu segenap kegiatan tersebut adalah para Kiyai atau ustadz-ustadz yang kompeten dalam bidangnya. Kegiatan kultural keagamaan itu terus menguat karena aktivitasnya tidak pernah berhenti.

Seiring dengan kelahiran, pernikahan, dan kematian, dakwah kultural yang kadang dilakukan secara verbal (lisan) itu terus bersemi dan memberi arti yang sangat kuat dalam membina shilaturrahmi antar jama'ah. Maka boleh dikata, meski secara organisatoris NU tidak serapi dan sebaik Muhammadiyah, namun dalam mengikat hubungan dan dalam jumlah kewargaan, NU di Banjarmasin jauh lebih banyak dibanding warga Muhammadiyah. Maka melihat kenyataan ini, alangkah baiknya NU bergerak dalam pembenahan organisasi, agar hal-hal yang tadinya mencair, liar, dapat dibina dalam suatu wadah yang rapi.

\section{E. Penutup}

Demikianlah analisis data atas aktivitas dakwah organisasi besar keagamaan Nahdlatul Ulama di Kota Banjarmasin, sehingga dapat disimpulkan bahwa Organisasi NU termasuk organisasi yang besar dari segi jumlah jama'ah, namun dari sisi lain NU belum nanpak sebagai 
organisasi yang kuat secara manajemen dan peran-peran organisasi, sebab gerak individu jama'ah NU lebih menonjol daripada peran secara organisasi.

Pada hakikatnya dakwah Nahdlatul Ulama secara organisasi dapat dikatakan mandul, karena antara organisasi dengan gerakan di lapangan itu terputus. Apa yang dilakukan oleh tokoh-tokoh Nahdlatul Ulama Kota Banjarmasin sebenarnya bukanlah cerminan organisasi, melainkan cerminan dari tokoh-tokoh itu sendiri. Mulai dari mesjid, amal usaha di bidang pendidikan, dan lain-lain, itu semua berdasarkan inisiatif individu, yang kadang mengaitkannya dengan organisasi, atau hanya sekedar berafiliasi.

Metode dakwah yang umum dilakukan oleh jama'ah Nudi Kota Banjarmasin juga masih berkisar pada metode bil lisan dan bil hal, tidak ada kelembagaan pendidikan ataupun dakwah melalui media atau dakwah bil kitabah. Namun demikian kontribusi dakwah jama'ah NU dalam mengembangkan dakwah tradisi NU seperti tahlilan, mauludan dll tetap berjalan.

\section{Daftar Pustaka}

Anshari, M. Hafi. Pemahaman dan Pengalaman Dakwah (Surabaya: alIkhlas, 1993

al-Asfihani, Al-Raghib. Mu'jam Mufradat al-Fazhil Quran, Beirut: Darul Fikri, th... .

Hamka. Tafsir al-Azhar, juz IV, Jakarta: Pustaka Panjimas, 1987.

Jamil, Muhamad Mukhsin dkk. Nalar Islam Nusantara, Jakarta: DPTI, 2007.

al-Maraghi, Ahmad Musthafa. Tafsir al-Maraghi, juz IV, Beirut: Darul Fikri, tth. 
Fahmi Riady, Pola Dakwah Nahdlatul Ulama di Kota Banjarmasin

Poerwadarminta, W.J.S. Kamus Umum Bahasa Indonesia, Jakarta: Balai Pustaka,1976.

Rakhmat, Jalaluddin. Rekayasa Sosial: Reformasi, Ravolusi, atau Manusia Besar? Bandung: Remaja Rosda Karya, 2000.

Shihab, Quraish. Tafsir al-Misbah Pesan, Kesan, dan Keserasian Alquran, volume 2, Jakarta:Lentera Hati.

--------. Membumikan Alquran: Fungsi dan Peran Wahyu dalam Kehidupan Masyarakat, Bandung: Mizan,1999.

Syukir, Asmuni. Dasar-Dasar Strategi Dakwah Islam (Surabaya: al-Ikhlas, 1983.

Tasmara, Toto. Komunikasi Dakwah, Jakarta: Gaya Media Pratama, 1997.

Ya'qub, Hamzah. Publisistik Islam: Teknik dakwah dan Leadership Bandung: Diponegoro, 1981.

Yunus, Mahmud. Kamus Arab Indonesia, Jakarta, Mahmud Yunus wa Dzurriyah, 1990

http://id.wikipedia.org, Dakwah (15 November 2010). 